Emina MOSTIĆ

Orijentalni institut Univerziteta u Sarajevu

E-mail: mostic.emina@gmail.com

Stručni rad/Professional article

UDK/UDC: 94(497:497.6)"408" (051)

DOI: https://doi.org/10.52259/historijskipogledi.2021.4.6.385

\title{
JOURNAL OF THE FACULTY OF PHILOSOPHY IN SARAJEVO (History, History of Arts, Archeology), posebno izdanje: Reflections on Life and Society in the Western Balkans. \\ Studies in the History of Bosnia and Herzegovina, knjiga 7, broj 2, Faculty of Philosophy, University of Sarajevo, Sarajevo 2020, 321 str.
}

Sedamdeseta godišnjica Filozofskog fakulteta Univerziteta u Sarajevu obilježena je u jeku pandemije COVID-19 koja je donijela nove modele proslave važnih datuma. Tako je Odsjek za historiju spomenutog fakulteta odlučio da

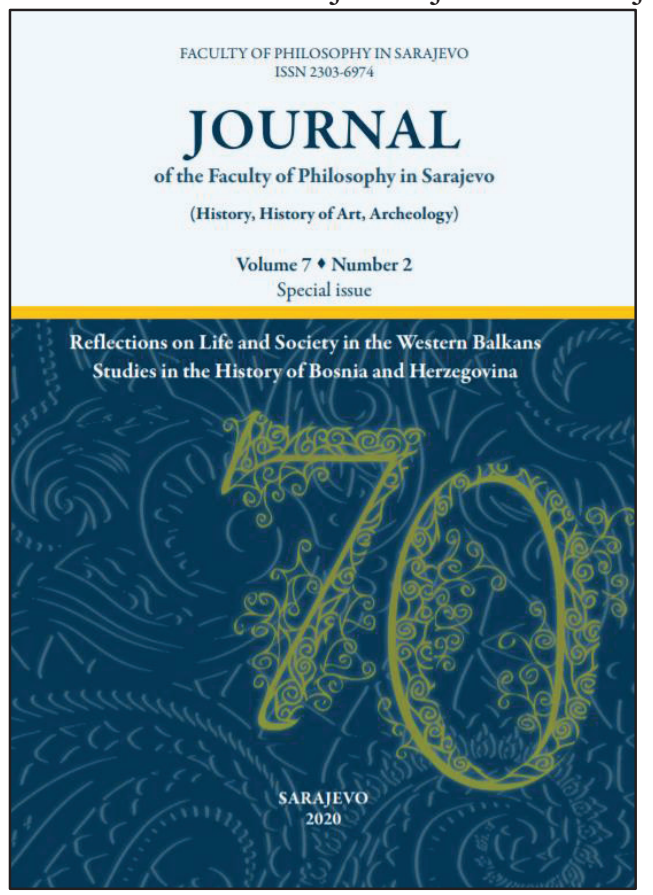
sedmi broj godišnjaka Filozofskog fakulteta Radovi (Historija, historija umjetnosti, arheologija) bude tematski zbornik radova posvećen godišnjici Odsjeka, Filozofskog fakulteta ali i Univerziteta u Sarajevu. Ideja urednikâ prof. dr. Amile Kasumović i doc. dr. Fahda Kasumovića bila je da se ova važna godišnjica iskoristi kao iskorak u uključivanju Odsjeka u globalne procese predstavljanjem odabranih radova na engleskom jeziku. Cilj je bio da se zainteresovanima za historiju Bosne i Hercegovine olakša pristup recentnim saznanjima te da ih se pozove na dijalog. Tematski zbornik naslovljen je Reflections on Life and Society in the W estern Balkans: Studies in the History of Bosnia and Herzegovina (Refleksije o društvu i životu na zapadnom Balkanu: Studije o historiji Bosne i Hercegovine) i čini ga 
dvanaest radova profesora i asistenata na Odsjeku za historiju koji su predstavljeni prema ustaljenoj hronološkoj matrici. Deset radova predstavljaju prijevode na engleski jezik ranije objavljenih radova ili poglavlja u knjigama. Dva rada su objavljena prvi put u ovom zborniku, to su radovi Almira Pece i Fahda Kasumovića. Zbornik ima i uvodnik urednikâ u kojem su predstavljeni ciljevi, ideje i namjere tima koji je radio na ovom zborniku. U uvodniku je dat $\mathrm{i}$ pregled najznačajnijih radova o historiji Bosne i Hercegovine objavljenih na engleskom jeziku s pozivom na intenziviranje takvih poduhvata u budućnosti.

Prvu skupinu radova, onih iz perioda starog vijeka čine rad Amre Šačić Beća i Salmedina Mesihovića, profesora na oblasti Stari vijek, Odsjeka za historiju Univerziteta u Sarajevu. Rad autorice Šačić Beća naslova Ancient Epigraphic Inscriptions as a Source for Research of the Oldest Past of Bosnia and Herzegovina Text Reconstruction and Analysis of Four Previously Unpublished Epigraphic Monuments bavi se latinskom epigrafijom odnosno novopronađenim epigrafskim spomenicima koji se tiču rimskih provincija Dalmacije i Panonije. U radu su predstavljena četiri nepoznata epigrafska spomenika: jedan miljokaz, nadgrobni spomenik s natpisom, natpis na opeci te votivnoj ari posvećenoj Jupiteru. Analizom ovih spomenika autorica se osvrnula na pitanja kao što su južna granica Panonije, rimske ceste te postojanje radionice za proizvodnju opeke na teritoriji savremene Bosne i Hercegovine. Naredni članak naslova Ovid and Illyricum čiji je autor Salmedin Mesihović govori o Publiju Ovidiju Nazonu, pjesniku zlatnog doba rimskog pjesništva koji se u svojim djelima referira na Ilirik. Pjesnik je, pod nedovoljno razjašnjenim okolnostima bio protjeran iz Rima u vrijeme ustanka u Iliriku kojeg je predvodio Baton Dezidijatski. Tokom izgnanstva, pisao je rimskim uglednicima nadajući se pomilovanju i ta njegova pisma sadrže podatke o ustanku. Osim pisama, Mesihović je analizirao i dva Ovidijeva djela Tristia i Epistulae ex Ponto. Najviše podataka o Iliriku i Ustanku Ovidije daje u pismima Germanikusu i Mesalinusu $\mathrm{u}$ kojem navodi pojedinosti o procesijama nakon pobjede u Iliriku te zarobljenicima među kojima je bio i Baton Dezidijatski. U radu je autor ponudio i tekstove na latinskom koji pokazuju kako je jedan od najznačajnijih rimskih pjesnika koristan izvor u proučavanju Velikog ilirskog ustanka.

Narednu cjelinu čine dva rada iz bosanskohercegovačke historije srednjeg vijeka. Esad Kurtović u svom radu naslova Vlachs and Stećak Tombstones analizom natpisa na stećcima i arhivskih dokumenata nudi podatke o Vlasima koji su sahranjivani ispod stećaka. Ovo pitanje je u historiografiji relativno zapostavljeno i njime se bave samo istraživači stećaka a manje oni koji se bave dokumentima. Kao i u radu Amre Šačić Beća i ovdje je naglašena važnost materijalnih spomenika i njihovo kontekstualiziranje zajedno sa sačuvanim arhivskim dokumentima. Autor je još jedanput potvrdio da se i vlaška skupina nalazi među zajednicom koja se u srednjovjekovnoj Bosni sahranjivala pod stećcima. Rad Almira Pece The 1444 Treaty between King Alfonso V of Aragon and Grand Duke Stjepan Vukčić govori o sporazumu između velikog vojvode bosanskog Stjepana Vukčića Kosače i aragonskog kralja Alfonsa V koji je 
postignut početkom 1444. godine. Peco navodi okolnosti koji se dovele do toga da se ciljevi i planovi jednog domaćeg vladara i moćnog vladara Mediterana usklade. Tako je vojvoda Stjepan postao vjerni sluga svoga zaštitnika Alfonsa V što mu je trebalo pomoći u nestabilnim okolnostima u Bosanskom kraljevstvu. Jedan od značaja ove povelje je i u tome što nam nudi dosta podataka o toponimima i prostoru koji je bio pod vlašću Stjepana Kosače. Kako bi ova povelja bila dostupnija drugim istraživačima, autor je u radu donio tekst na latinskom, prijevod na engleskom jeziku sa slikama originalnog dokumenta u visokoj rezoluciji.

Grupu radova iz oblasti novog vijeka i savremenog doba otvara izvorni naučni rad Fahda Kasumovića The Changing Face of Fiscal Policy in the Periphery of the World of Islam: The Gypsy Poll Tax in Ottoman Bosnia, c. 1690 s-1856 u kojem autor na osnovu primarnih i do sada neobjavljenih izvora ispituje poreznu politiku Osmanskog Carstva u Bosni i to njezin aspekt koji tiče glavarine koju su plaćali pripadnici romske populacije. Autor je najprije predstavio regionalne razlike koje su primjetne u naplati glavarine romskoj populaciji, važnost glavarine za provinciju te promjene u poreznim strategijama Carstva. Autor iznosi i napore koju je centralna vlada ulagala kako bi skupila potrebna sredstva za funkcioniranje države te nastoji da promjenu poreske politike naplate glavarine Romima kontekstualizira u okviru ekonomskih i poreskih promjena u Osmanskom Carstvu. Sljedeći je članak Edina Radušića Narratives on the Beginning of the 1875-1878 Uprising in Bosnia and Herzegovina in the British Public Discourse koji govori o refleksijama istočne krize u britanskom diskursu. U svoju analizu autor je uključio korespondencije konzula, britanske novine i javno mnijenje. Autor hronološki prati razvoj diskursa u britanskoj štampi u vrijeme ustanka u Bosni i Hercegovini i zaključuje da je riječ o pripremnoj fazi, da diskurs nije bio predominantan te da je još uvijek moguće pronaći tekstove koje problemima pristupaju multiperspektivno i kritički. Ipak, Britanci su za Evropu čuvali epitet civilizacije dok su Osmanlije bile „Drugo, barbari, teret kojeg se trebalo riješiti.“

Naredni članak također problematizira jedno pitanje iz novije historije Bosne i Hercegovine. Amila Kasumović u radu Activities of the Consular Missions in Bosnia and Herzegovina in the First Years of the Austro-Hungarian Occupation 1878 - 1881 donosi retrospektivu konzularnih aktivnosti u Bosni i Hercegovini u doba Osmanskog Carstva te analizira promjene koje su nastupile nakon austrougarske okupacije. Naime, na cijeloj teritoriji Osmanskog Carstva vladao je sistem kapitulacija - ugovora koje je Carstvo potpisivalo sa evropskim zemljama. Ovi ugovori su bili izuzetno nepovoljni za Carstvo, pružali su široke jurisdikcije konzulima. Kako je ta praksa primjenjivana i na teritoriji Bosne i Hercegovine, Austro-Ugarska je prve godine nakon okupacije posvetila raskidanju ugovora i posljedično tome uvedena je nova praksa otvaranja stranih konzulata u Bosni i Hercegovini. Time je učinjen još jedan korak u smanjenju suverenosti sultana nad Bosnom jer je sada Monarhija bila ta koja je donosila odluke o imenovanju konzula. Zanimljivo je i da je Monarhija ukinula svoje 
konzulate u Bosni čime je njena okupacija podignuta na razinu državnopravnog odnosa u čemu autorica vidi još jedan pokazatelj da je Monarhija činila sve da što čvršće veže Bosnu i Hercegovinu.

Skupina radova koja tematizira savremenu historiju Bosne i Hercegovine započinje radom Minele Radušić Bosnia and Herzegovina in the AustroHungarian Period (Articles and Discussions): between Historical Facts and Ideological Revisionism. Rad je nastao na osnovu analize djela Bosna $i$ Hercegovina u vrijeme austrougarske vladavine (članci $i$ rasprave) autora Hamdije Kapidžića. Autorica je na primjeru spomenutog djela analizirala način na koji je socijalistička historiografija u Bosni i Hercegovini promatrala ujedinjenje Jugoslavije 1918. godine. U radu je moguće čitati o akademskom profilu znanstvenika koji su se bavili ovim pitanjem, relevantnosti njihovih izvora s ciljem da utvrdi znanstvenu utemeljenost istraživanja i da li je i u kojoj mjeri u njima prisutan historijski revizionizam. Zatim, Husnija Kamberović u svom članku Walking on Thorns: The Mostar Symposium of 1966. govori o jednom od značajnih događaja iz bosanskohercegovačke historije 20. stoljeća. Naime, nakon završetka Drugog svjetskog rata komunistička vlast je imala poseban odnos prema Hrvatima, smatrajući da će tako spriječiti revitalizaciju ustaškog pokreta. Takav odnos trajao je do Mostarskog savjetovanja iz 1966. godine koje je za cilj imalo da se prostor zapadne Hercegovine ponovo integrira u okvire Bosne i Hercegovine a zatim i u jugoslovenske okvire. Kako bi to postigli, komunisti su priznali da su vodili pogrešnu politiku prema Hrvatima što je onda dovelo do različitih reakcija kako u medijskim tako i u političkim krugovima, čemu je autor također posvetio značajnu pažnju. U članku Identity Transformation of Migrants from Bosnia and Herzegovina in post-1960s Germany Amir Duranović predstavlja rezultate terenskog istraživanja koje je provedeno u Berlinu. Autor se fokusirao na vjerski život jugoslovenskih/bosanskih muslimana i njihove aktivnosti u organizovanim skupinama - džematima te na transformacije identiteta u okolnostima koje su oblikovane političkim promjenama kako u tadašnjoj Njemačkoj tako i u Jugoslaviji/ Bosni i Hercegovini. Kako su u historiografiji češće zastupljena istraživanja o migracijama bosanskohercegovačkog stanovništva nakon 1878 . godine, autor je ovim radom želio dati svoj doprinos u proučavanju kasnijih migracija ka Zapadu.

Još jedan rad iz savremene historije Bosne i Hercegovine Pax Americana The Republic of Bosnia and Herzegovina and International Diplomacy from the Washington to the Dayton Peace Agreement (18 March 1994 - 21 November 1995) čiji je autor Zijad Šehić analizira planove i aktivnosti koje je provodila međunarodna zajednica kako bi okončala rat u Bosni i Hercegovini. Pri tome, autor sagledava diplomatiju i ponašanje pojedinih zemalja kako bi naglasio svu kompleksnost postizanja mira. Autor zaključuje kako je mirovni sporazum donio završetak rata, ali ne i uspostavljanje funkcionalne države jer rat na određeni način još uvijek postoji u bosanskohercegovačkom društvu. Članak Melise ForićPlasto Divided Past for a Divided Future!? The 1992-1995 War in the Current 
History Textbooks in Bosnia and Herzegovina na određeni način nadovezuje se na Šehićev zaključak. Naime, autorica je kroz analizu načina na koji je rat $1992-$ 1995. predstavljen u savremenim udžbenicima historije u Bosni i Hercegovini zaključila kako različiti pristupi ratu, ratnim zločinima i njihovim počiniteljima samo doprinose produbljenju razlika među školskom djecom, naročito $u$ sredinama u kojima žive pripadnici različitih etno-nacionalnih skupina.

Profesori na Odsjeku za historiju Univerziteta u Sarajevu ovim zbornikom željeli su svoj odsjek ali i Univerzitet (bolje) pozicionirati u savremenom, globalnom svijetu, podstaći na suradnju i dijalog sa naučnicima širom svijeta te na dostojan način obilježiti godišnjicu Odsjeka za historiju. Ovaj poduhvat će zasigurno doprinijeti povećanju vidljivosti domaćih istraživača, osigurati im širu publiku te doprinijeti da pozitivni aspekti globalizacije jače zažive u Bosni i Hercegovini. Njime je šira čitalačka publika dobila uvid u teme kojima se domaći istraživači bave i ostaje nada da ćemo u budućnosti svjedočiti većem broju sličnih inicijativa. 